\title{
Analisis Marketing Mix dalam Meningkatkan Jumlah Pembeli Ayam Geprek Mbok Moro Kota Kediri
}

\author{
Forijati' ${ }^{1}$, Ridwan ${ }^{2}$ \\ forijati@unpkediri.ac.id ${ }^{1}$,ridwan@unpkediri.ac.id² \\ Program Studi Magister Pendidikan Ekonomi ${ }^{1}$, Program Studi PG-PAUD2 \\ Universitas Nusantara PGRI Kediri1,2
}

\begin{abstract}
The purpose of this research is to find out how the marketing mix is used to increase the number of buyers in the Mbok Moro Geprek Chicken Business. Marketing activity is an attempt to offer consumers the products they are produced. Marketing is a very determining factor for the survival of a company, so it is very important for business owners to pay attention to the marketing mix that the company runs. The research method used mixed method. The subject of this research was Mbok Moro geprek chicken business and ata collection used interviews and observations. Data analysis techniques used marketing mix analysis. The variables of marketing mix were product, price, place and promotion. The result of this research showed that consumers' decision to buy Mbok Moro Geprek Chicken had many reasons, they are: the place was strategic and the price of product was afforadable. The recommendation of this research is that the products of Mbok Moro geprek chickens must be more varied and innovative in packaging and online marketing and also improving brand.
\end{abstract}

Keywords: market segment, marketing mix, marketing

\section{ABSTRAK}

Tujuan penelitian ini adalah untuk mengetahui bagaimana marketing mix yang digunakan untuk meningkatkan jumlah pembeli pada usaha ayam geprek Mbok Moro. Kegiatan pemasaran merupakan suatu usaha untuk menawarkan pada konsumen hasil produksinya. Pemasaran merupakan suatu faktor yang sangat menentukan bagi kelangsungan hidup sebuah perusahaan, sehingga sangatlah penting bagi pemilik usaha untuk memperhatikan marketing mix yang dijalankan perusahaan. Metode Penelitian ini adalah dengan menggunakan mixed method. Subjek penelitian adalah usaha ayam geprek Mbok Moro, pengumpulan data dengan menggunakan wawancara dan observasi. Teknik analisis data yang digunakan adalah analisis marketing mix. Variabel pemasaran marketing mix yang diteliti adalah produk, price, place dan promotion. Hasil dari penelitian ini adalah keputusan yang diambil konsumen dalam pembelian ayam geprek Mbok Moro adalah pemilihan tempat yang strategis dan harga produk yang terjangkau. Rekomendasi dari penelitian ini adalah produk dari ayam geprek Mbok Moro harus lebih bervariasi dan berinovasi dari pengemasan maupun pemasaran secara online dan juga meningkatkan brand.

Kata Kunci: segment market, marketing mix, pemasaran

\section{PENDAHULUAN}

Seorang pengusaha akan berusaha untuk memenangkan persaingan dan menjadi yang terbaik, oleh sebab itu harus menampilkan produk yang terbaik dan dapat memenuhi selera konsumen yang selalu berkembang (Kotler, 2002). Salah satu tujuan mendirikan usaha adalah untuk mencari keuntangan atau laba. Pemasaran dalam suatu usaha merupakan hal yang sangat penting. Pemasaran dapat di definisikan sebagai kegiatan manajerial dan di dalam kegiatan itu ada individu maupun kelompok yang akan mendapatkan apa yang mereka inginkan dan butuhkan (needs and wants), dengan kegiatan mempertukarkan produk atau menawarkan pada pihak lain (Da Aulia, 2013 dalam Daryanto, 2019). Dari pengertian diatas, pemasaran merupakan kegiatan antara manajerial dan 


\section{Efektor, Vol. 7. No.1 Tahun 2020, Pages 49-58 Forijati, Ridwan}

seni untuk menjual produk. Dalam hal ini diperlukan sebuah strategi untuk menjaring pangsa pasar. Menurut Kotler (2002) menjadi seorang pengusaha yang terbaik, harus menguasai dan dapat memenangkan persaingan yaitu dengan bagaimana menampilkan hal yang terbaik dari produknya untuk memenuhi selera dan keinginan dari konsumen.

Salah satu strategi yaitu dengan pelayanan yang ramah dan memuaskan konsumen akan produk yang ditawarkan (Forijati, 2019). Suatu analisis tentang pemasaran akan berguna untuk mengetahui kekuatan dan kelemahan dari suatu usaha, sehingga pengusaha dapat memperbaiki kelemahan dan mampu mempertahankan usahanya dengan kekuatan yang dipunyai. Dalam dunia pemasaran yang dinamis dan dengan jangkauan yang sangat luas, terdapat berbagai tahapan yang harus dilalui barang maupun jasa sehingga sampai di tangan konsumen. Oleh sebab itu, berbagai teori tentang pemasaran dengan strateginya yang dikenal dengan bauran pemasaran atau marketing mix yang di kenal dengan $4 \mathrm{P}$ yaitu produk (product), harga (price), tempta (place) dan promosi (promotion).

Menurut Cannon, Perreault dan McCarthy (2008), bauran pemasaran atau marketing mix merupakan suatu kombinasi dari variabel atau suatu kegiatan dan merupakan inti dari suatu sistem pemasaran. Perusahaan mengendalikan variabel yang terbesar yang mempengaruhi keputusan konsumen untuk membeli produknya. Dengan demikian perusahaan mengelola dan mengkoordinasikan berbagai variabel dalam marketing mix untuk menjaring pangsa pasar. Lebih lanjut Kotler dan Keller (2008) menyatakan bahwa keputusan pembelian merupakan suatu keputusan pembeli dengan mengenal preferensi atas berbagai merek yang ada dalam berbagai pilihan. Semakin banyak tawaran, pembeli akan semakin jeli dalam memilih barang atau jasa yang dibutuhkan dan diinginkan, sehingga pembeli memerlukan berbagai pertimbangan dalam memutuskan untuk membeli. Menurut Buchari (2004: 96) pembeli mempunyai keputusan untuk membeli suatu produk barang atau jasa dengan mencari informasi yang berkaitan dengan produk tersebut seperti harga, preferensi produk, selain itu juga mempertimbangkan jarak maupun dipengaruhi oleh promosi dari pemilik usaha yang di kenal dengan istilah bauran pemasaran.

Marketing mix juga merupakan sarana perencanaan pemasaran akan produk barang atau jasa yang disesuaikan dengan kemampuan pembeli untuk membeli barang tersebut. Rencana tersebut juga berkaitan dengan tempat usaha maupun dengan promosi yang akan dilakukan oleh perusahaan (Bannet, 1997). Disamping itu bauran pemasaran yang merupakan kombinasi dari variabel produk, harga, tempat dan promosi akan mempengaruhi keputusan pembeli dalam menentukan pembelian atas suatu produk ( Oetama, 2011). Dapat dijelaskan bahwa bauran pemasaran terdiri dari :

\section{Product (produk)}

Produk menurut Lye et al (2004), Tjiptono (1997) adalah segala sesuatu yang dapat ditawarkan maupun dijual oleh produsen dan barang tersebut dapat berupa tangible maupun intangible sehingga dapat memenuhi kebutuhan atau keinginan pasar juga kebutuhan konsumen. Lebih lanjut Tjiptono (1997) menyebutkan bahwa produk mempunyai unsur-unsur yang dipandang penting oleh konsumen dan unsur tersebut dapat menjadi dasar pertimbangan untuk membeli barang atau jasa tersebut. Salah satu unsur dari produk tersebut berupa keunggulan, 


\section{Efektor, Vol. 7. No.1 Tahun 2020, Pages 49-58 \\ Forijati, Ridwan}

kualitas produk, merek, kemasan, garansi, pelayanan dan sebagainya. Dari berbagai unsur produk, konsumen akan mempunyai banyak pilihan alternatif untuk memutuskan dan mempertimbangkan pembelian barang atau jasa sesuai dengan kebutuhan. Akan tetapi tidak hanya faktor produk saja yang mempengaruhi keputusan membeli faktor pelayanan, (Selang, 2013).

\section{Price (Harga)}

Dalam kegiatan pemasaran, penentuan harga menjadi sangatlah penting karena harga merupakan salah satu daya tarik konsumen dalam memutuskan membeli sebuah barang atau jasa. Menurut Tjiptono (1997), Kotler dan Amstrong harga adalah suatu satuan moneter atau dalam bentuk ukuran lain yang dibayarkan pembeli atau konsumen untuk mempoleh suatu barang atau jasa.

Penentuan harga tentu saja harus mempertimbangkan berbagai faktor antara lain bagaimana kompetisi dalam pasar. Seorang pengusaha dalam menetapkan harga untuk produknya harus memahami dan mengetahui variabel yang mempengaruhi pembentukan harga tersebut dan juga bagaimana menangani markup, diskon atau beberapa hal yang berkenaan dengan harga produk. Tujuan utama nya adalah untuk meningkatkan penjualan, mempertahankan market share maupun mencapai laba usaha yang optimal (Engel, J; Blackwell R, 2004) Adapun variabel dari harga tersebut menurut Kotler (2002) adalah : 1) bagaimana penentuan harga disesuaikan dengan daya beli konsumen 2) harga disesuaikan dengan kualitas produk barang atau jasa 3) apakah penentuan harga juga berhubungan dengan pemberian diskon atau potongan harga 4) adanya cashback apabila produk yang dijual mengalami kerusahaan.

\section{Place (Tempat)}

Place atau tempat usaha adalah tempat membuat barang atau jasa sekaligus dapat juga tempat untuk memperjual belikan barang atau jasa. Menurut Engel, J; Blackwell R, 2004; Tjiptono, 2000, ada beberapa hal yang menjadi faktor pemilihan lokasi atau tempat usaha yaitu : 1) lokasi yang mudah untuk di jangkau oleh pembeli atau konsumen (aksesbilitas), 2) lokasi tempat usaha mudah terlihat sehingga mudah dikenali oleh pembeli atau konsumen (visibilitas) 3) tempat usaha dapat dijangkau oleh lalu lintas angkutan 4) terdapat tempat parkir yang luas.

Lebih lanjut menurut tempat usaha merupakan salah satu faktor yang penting dan krusial yang mempengaruhi kesuksesan suatu usaha, hal ini karena lokasi penentu dengan pasar potensial. Dalam penentuan tempat usaha berkaitan dengan penyaluran barang atau jasa ke tangan konsumen. Selain penentuan tempat, kenyamanan tempat usaha baik interior maupun eksterior tempat usaha juga mempengaruhi keputusan pembeli atau konsumen dalam menentukan pembelian barang atau jasa tersebut.

\section{Promotion (promosi)}

Promosi merupakan suatu kegiatan untuk mengenalkan dan mengkomunikasikan produk atau jasa yang dijual kepada pembeli atau konsumen. Menurut Ali (2008) beberapa alat promosi antara lain iklan, personal selling, sales promosion, direct selling, dan iklan merupakan alat utama untuk meningkatkan penjualan. Sedangkan menurut Rigopoulou et al. (2008) menyatakan bahwa dalam pembelian layanan purna jual mempunyai peran yang sangat penting dalam menjalin hubungan antara pembeli dengan penjual. 


\section{Efektor, Vol. 7. No.1 Tahun 2020, Pages 49-58 \\ Forijati, Ridwan}

Menurut Tanton dalam Daryanto, 2019 promosi merupakan salah satu faktor bauran pemasaran (marketing mix) yang digunakan untuk mempengaruhi atau membujuk dan mengingatkan konsumen atas produk barang atau jasa suatau usaha. Dengan promosi, tujuan dari perusahaan adalah mengkomunikasikan produknya sehingga pembeli atau calon pembeli merasa tertarik dan kemudian memutuskan untuk membeli produk tersebut. Promosi dapat dipandang sebagai suatu arus informasi yang dibuat untuk mengarahkan pembeli sehingga tercipta suatu pertukaran (Basu Swasta, 2001)

Cannon, Perreault dan McCarthy (2008:70) menjelaskan ada beberapa indikator yang digunakan untuk promosi dan mempengaruhi keputusan suatu pembelian, indikator tersebut adalah : 1) tujuan promosi secara keseluruhan adalah mempengaruhi perilaku konsumen 2) tujuan promosi adalah untuk menginformasikan atau mengedukasi konsumen atas sebuah produk barang atau jasa 3) Promosi bertujuan untuk membujuk konsumen untuk memutuskan membeli produk tersebut 4 ) promosi bertujuan juga untuk mengingatkan konsumen atas produk barang atau jasa.

Dari ke empat bauran pemasaran (marketing mix) bertujuan untuk meningkatkan penjualan atau meningkatkan jumlah pembeli atas produk barang atau jasa. Keputusan pembelian merupakan suatu keputusan dari pembeli atau konsumen atan preferensi atas merek-merek yang ada dalam kumpulan pilihan pilihan yang dimiliki konsumen. (Kotler dan Keller, 2008). Terdapat lima tahapan keputusan konsumen dalam menentukan pembelian barang atau jasa yaitu 1) Pengenalan masalah, yaitu bagaimana pembeli membutuhkan barang atau jasa. 2) mencari informasi barang atau jasa yang dibutuhkan atau diinginkan 3) dari beberapa informasi, konsumen mengevaluasi beberapa alternatif dengan mempertimbangkan factor factor bauran pemasaran seperti produk, harga, tempat dan promosi 4) dari berbagai alternative dan pertimbangan, konsumen mempunyai keputusan dalam pembelian 5) perilaku pasca pembelian terlaksana.

Dari uraian latar belakang di atas, tujuan dari penelitian ini adalah untuk mengetahui bagaimana marketing mix dapat meningkatkan jumlah pembelian pada usaha ayam geprek Mbok Moro Kota Kediri. Usaha ayam geprek Mbok Moro merupakan sebuah usaha memproduksi sekaligus menjual belikan ayam geprek dengan berbagai inovasi produk. Dengan menganalisis marketing mix diharapkan bahwa terdapat peningkatan jumlah pembeli sehingga usaha ini semakin berkembang.

\section{METODE PENELITIAN}

Penelitian ini menggunakan metode penelitian mixed methods atau penelitian campuran yaitu penelitian yang menggabungkan penelitian kuantitatif dengan kualitatif. Metode penelitian kombinasi merupakan metode yang memadukan atau menggabungkan metode kuantitatif dan metode kualitatif, dan dapat digunakan secara bersamaan dalam suatu kegiatan penelitian yang akhirnya akan diperoleh hasil penelitian yang menyeluruh (komprehensif), objektif dan reliabel (Sugiono, 2014). Sedangkan menurut Creswell (2013), metode penelitian mixed method merupakan penelitian campuran dan juga pendekatan penelitian ini mengkombinasikan antara penelitian kualitatif dan penelitian kuantitatif. Pada penelitian ini penelitian kuantitatif digunakan untuk melihat bagaimana tanggapan dari pembeli atas produk, harga, tempat dan promosi dari ayam geprek Mbok Moro, 


\section{Efektor, Vol. 7. No.1 Tahun 2020, Pages 49-58 \\ Forijati, Ridwan}

sedangkan data kualitatif dideskripsikan untuk memberikan gambaran tentang marketing mix usaha ayam geprek Mbok Moro. Data kualitatif menurut Moleong (2012) merupakan pendekatan deskriptif yang menggunakan data dan berupa kata-kata ataupun gambar dan bukan angka.

Subjek penelitian adalah konsumen usaha ayam geprek Mbok Moro dengan jumlah 80 orang. Teknik pengambilan data dengan kuesioner dan wawancara. Teknik analisis data, untuk data kuantitatif dengan memakai analisis persentase untuk memetakan tanggapan konsumen terhadap produk ayam geprek Mbok Moro, harga, tempat penyajian dan promosi. Sedangkan untuk data kualitatif di deskripsikan dengan analisis konten diskrip kualitatif. Analisis ini digunakan adalah untuk mendeskripsikan aspek aspek dan karakteristik dari suatu pesan (Eriyanto, 2011), pada penelitian ini analisis konten dari marketing mix yaitu dari aspek produk, harga, tempat dan promosi.

\section{HASIL DAN PEMBAHASAN}

\section{Analsisis Prosentase}

Tabel 1. Analisis Persentase Persepsi Pembeli

\begin{tabular}{ccccccccc}
\hline \multirow{2}{*}{ Keterangan } & \multicolumn{2}{c}{ Produk } & \multicolumn{2}{c}{ Price } & \multicolumn{2}{c}{ Place } & \multicolumn{2}{c}{ Promotion } \\
\cline { 2 - 9 } & Frek. & $(\%)$ & Frek. & $(\%)$ & Frek. & $(\%)$ & Frek. & $(\%)$ \\
\hline Tanggapan $(+)$ & 63 & 78.75 & 65 & 81.25 & 73 & 91.25 & 69 & 86.25 \\
\hline Tanggapan (-) & 17 & 21.25 & 15 & 18.75 & 7 & 8.75 & 11 & 13.75 \\
\hline & 80 & 100.00 & 80 & 100.00 & 80 & 100.00 & 80 & 100.00 \\
\hline
\end{tabular}

\section{Dari segi kebijakan produk}

Dari konsumen yang membeli produk ayam geprek Mbok Moro adalah pelajar dan mahasiswa (76\%), umum (24\%). Tanggapan dari responden akan produk ayam geprek. Dari tabel diatas, tanggapan konsumen terhadap produk ayam geprek Mbok Moro menunjukan $78.75 \%$ positif, artinya konsumen menerima dengan baik produk ayam geprek karena sesuai dengan selera dari konsumen yang sebagian besar siswa dan mahasiswa. Produk ayam geprek Mbok Moro, merupakan produk kuliner yang sangat disukai karena rasa dan penyajiannya yang menggugah selera.

\section{Kebijakan harga}

Dari tabel diatas disimpulkan bahwa tanggapan konsumen terhadap harga yang dikenakan pada produk adalah $81.25 \%$ positif harga sudah sesuai dengan keuangan konsumen dan terjangkau. Harga produk dari ayam geprek Mbok Moro dengan pilihan paket minum yang dapat dipilih oleh konsumen. Harga produk kuliner ayam geprek Mbok Moro yang tidak mahal, sehingga dari kalangan mahasiswa sampai dengan siswa disekitar tempat usaha tersebut menjadi langganan dari usaha kuliner tersebut.

\section{Kebijakan place (tempat)}

Dari tabel diatas, kebijakan tempat usaha menurut tanggapan dari konsumen sebanyak $91.25 \%$ positif yang artinya bahwa tempat usaha ayam geprek Mbok Moro sangat strategis, karena dekat dengan tempat pendidikan yaitu SMP, MAN dan juga perguruan tinggi. Disamping itu tempat usaha juga dekat permukiman penduduk dan pasar. Karena tempat yang strategis dan terjangkau, pembeli merasa lebih mudah untuk membeli produk ayam geprek Mbok Moro. 


\section{Efektor, Vol. 7. No.1 Tahun 2020, Pages 49-58}

Forijati, Ridwan

\section{Kebijakan promotion (promosi)}

Dari tabel diatas, $86.25 \%$ konsumen menyatakan bahwa promosi ayam geprek Mbok Moro memuaskan (positif) yang artinya bahwa promosi yang dilakukan sudah baik karena disamping secara offline (dari mulut ke mulut) juga melalui beberapa sosial media baik facebook, instagram maupun whatssup. Disamping itu promosi dilakukan dengan memakai stand banner di depan tempat usaha yang cukup terlihat karena sangat menarik.

\section{Analisis Marketing Mix}

Dari hasil observasi dan wawancara di gambarkan sebagai berikut :

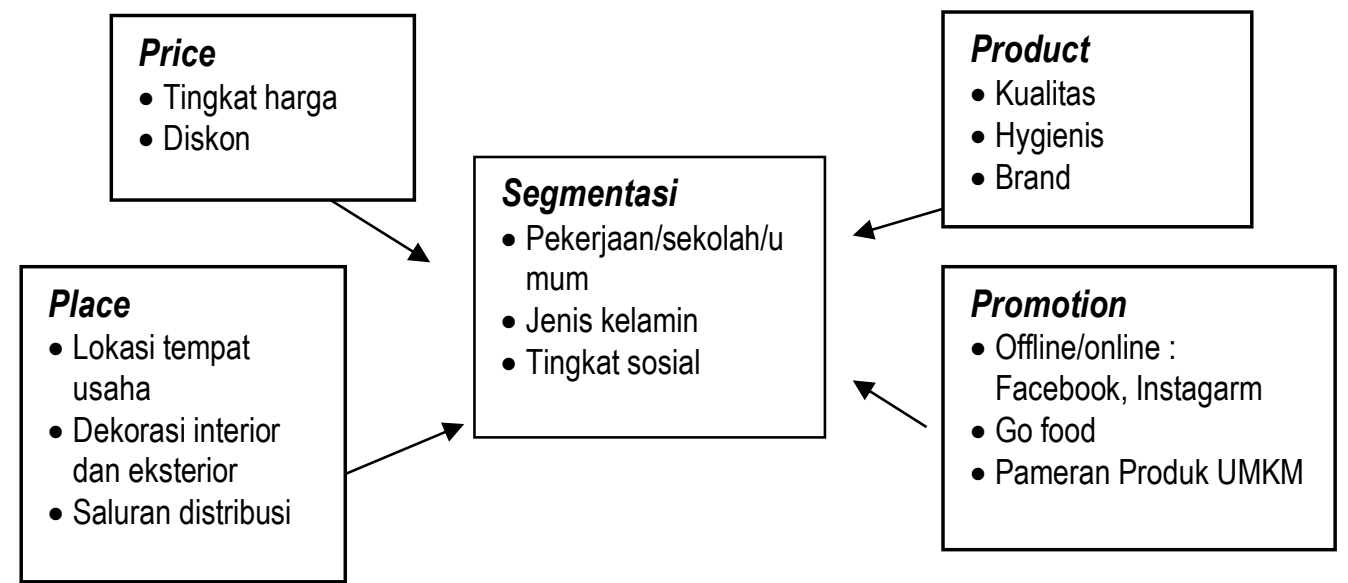

Gambar 1. Marketing mix usaha ayam geprek Mbok Moro

Dari hasil wawancara diperoleh data sebagai berikut :

\section{Kebijakan Produk}

Produk yang di tawarkan oleh usaha ayam geprek Mbok Moro adalah olahan ayam dengan variasi sambel dengan level kepedasan yang bervariasi. Dari hasil wawancara produk yang ditawarkan ini mempunyai kualitas yang terjamin higienisnya. Bahan baku yang diperoleh berasal dari pasar yang dekat dengan tempat usaha. Ciri khas ayam geprek Mbok Moro Kota Kediri adalah menu dengan lombok limo dan loro (cabe dua dan lima). Keunggulan dari produk ini adalah mempunyai citra rasa yang khas yang disukai oleh pelajar, mahasiswa ataupun masyarakat umum, Pada elemen ini, pelayanan yang ramah dan memuaskan merupakan kelebihan dari usaha ini, konsumen tidak menunggu lama dalam menunggu pesanan yang di inginkan. Kelemahannya adalah belum adanya informasi jika produk itu habis, sehingga ada beberapa konsumen yang kembali karena persediaan produk sudah habis (Forijati, 2019). Adapun hasil dari observasi dan wawancara dapat disajikan sebagai berikut: 
Efektor, Vol. 7. No.1 Tahun 2020, Pages 49-58

Forijati, Ridwan

Tabel 2. Standar Indikator Produk Ayam Geprek Mbok Moro

\begin{tabular}{|c|c|c|c|}
\hline Uraian & $\begin{array}{l}\text { Standar } \\
\text { indikator }\end{array}$ & $\begin{array}{l}\text { Kondisi Saat } \\
\text { ini }\end{array}$ & $\begin{array}{c}\text { Permasalahan, Kebutuhan Pengembangan Usaha untuk } \\
\text { meningkatkan jumlah pembeli }\end{array}$ \\
\hline $\begin{array}{l}\text { Produk ayam } \\
\text { geprek Mbok } \\
\text { Moro }\end{array}$ & $\begin{array}{l}\text { Penyediaan } \\
\text { bahan baku } \\
\text { Ayam dan bahan } \\
\text { pendukung } \\
\text { seperti : } \\
\text { Tahu krispi } \\
\text { Tempe krispi } \\
\text { Terong krispi } \\
\text { Jamur krispi }\end{array}$ & $\begin{array}{l}\text { Ayam diperoleh } \\
\text { dari peternak } \\
\text { sekitar. Dan } \\
\text { bahan baku } \\
\text { penolong di } \\
\text { peroleh dari } \\
\text { pasar yang } \\
\text { dekat dengan } \\
\text { tempat usaha }\end{array}$ & $\begin{array}{l}\text { Permasalahan : } \\
\text { Tidak ada quality control tiap produksi dan blm ada } \\
\text { manajemen mutu, blm mengembangkan produk, blm } \\
\text { menggunakan teknologi produksi, kemasan produk kurang } \\
\text { menarik. } \\
\text { Kebutuhan : } \\
\text { Adanya manajemen mutu dan menggunakan teknologi dalam } \\
\text { pengemasan produk dan juga inovasi produk sehingga lebih } \\
\text { menarik. } \\
\text { Pengembangan usaha : } \\
\text { Menggunakan teknologi untuk meningkatkan penjualan. } \\
\text { Perbaikan mutu : } \\
\text { perbaikan terhadap cita rasa dan penambahan menu makanan } \\
\text { penambahan variasi sambal yang beraneka rasa }\end{array}$ \\
\hline
\end{tabular}

\section{Kebijakan Price (Harga)}

Harga yang ditawarkan usaha ini adalah dengan harga unit maupun harga paket, harga per unit/bungkus Rp 10.000,- dan kalau harga paket dengan minuman Rp 12.000/porsi, sedangkan menu tambahan seperti tahu krispi, tempe krispi, jamur krispi dan terong krispi di jual tersendiri. Pada usaha ayam geprek Mbok Moro untuk menetapkan harga yaitu dengan 1) melihat posisi persaingan dalam usaha yang sama, karena pembeli tentu saja akan melihat harga pertama kali ketika mereka memutuskan untuk membeli produknya. Usaha ayam geprek Mbok Moro dalam menentukan harganya dengan memberikan harga yang relatif terjangkau konsumen, dan melayani pembelian dalam bentuk paket yaitu dengan minumnya. 2) Penetapan harga juga dilihat dari kemampuan daya beli dari pembeli yang tentu saja karena makanan cepat saji, harga dipatok tidak mahal juga tidak terlalu murah dan disesuaikan dengan cita rasa. 3) Faktor lainnya adalah biaya, dengan menekan biaya produksi dan biaya bahan baku, penetapan harga dapat ditentukan,sehingga usaha ayam geprek Mbok Moro mendapatkan keuntungan karena sudah ada perencanaan produksi dan perencanaan harga. Penentuan harga tentu saja dengan melihat komposisi dari produk yang akan dijualnya. Dari hasil wawancara dapat di simpulkan dalam tabel di bawah ini :

Tabel 3. Standart Indikator Harga Ayam Geprek Mbok Moro Kediri

\begin{tabular}{llll}
\hline \multicolumn{1}{c}{ Uraian } & \multicolumn{1}{c}{$\begin{array}{c}\text { Standar } \\
\text { indikator }\end{array}$} & \multicolumn{1}{c}{ Kondisi saat ini } & $\begin{array}{c}\text { Pengembangan usaha } \\
\text { untuk meningkatkan jumlah } \\
\text { pembeli }\end{array}$ \\
\hline Price / Harga : & Harga yang & - Harga pada usaha ayam geprek & Di ketemukan tempat \\
Kisaran harga, daya saing, & terjangkau untuk & Mbok Moro di sesuaikan dengan & pembelian bahan pokok dan \\
tingkat marjin, mahal/murah, & pembeli & kemampuan pembeli dan dengan & bahan penolong yang lebih \\
dll. & & pembandingan usaha ayam & bersaing (murah), sehingga \\
& geprek yang serupa yang ada di & harga bisa ditekan lebih \\
& kota Kediri. & murah lagi. \\
& - Harga ayam geprek Mbok Moro & \\
& dengan berbagai variasinya, bisa & \\
& dibayar cash di tempat atau & \\
& dengan melalui go food. & \\
& & \\
& &
\end{tabular}




\section{Efektor, Vol. 7. No.1 Tahun 2020, Pages 49-58 \\ Forijati, Ridwan}

\section{Kebijakan Place (Tempat Usaha)}

Tempat usaha ayam geprek Mbok Moro berada di desa Rejomulyo Kota Kediri, yang dekat dengan perguruan tinggi dan sekolah. Oleh karena itu tempat usaha ini dapat dijangkau baik dengan kendaraan umum baik roda dua maupun roda empat. Saluran distribusi pada usaha ayam geprek Mbok Moro yaitu dengan langsung konsumen datang ke tempat usaha untuk membeli, maupun dapat melakukan dengan melalui go food. Dari hasil pengambilan data dapat di analisis dan disimpulkan sebagai berikut:

Tabel 4. Standar Indikator Place/ Tempat Usaha Ayam Geprek Mbok Moro Kediri

\begin{tabular}{|c|c|c|c|}
\hline Uraian & Standar Indikator & $\begin{array}{l}\text { Kondisi saat ini dan } \\
\text { rencana pengembangan }\end{array}$ & $\begin{array}{c}\text { Pengembangan usaha } \\
\text { untuk meningkatkan } \\
\text { jumlah pembeli }\end{array}$ \\
\hline $\begin{array}{l}\text { Place / Tempat/ Lokasi : } \\
\text { Akses pasar, lokasi usaha, letak } \\
\text { outlet, jalur pemasaran, dll. }\end{array}$ & $\begin{array}{l}\text { - Lokasi dan suasana } \\
\text { seperti warung pada } \\
\text { umumnya } \\
\text { - Tempat usaha dekat } \\
\text { dengan kampus dan } \\
\text { sekolah }\end{array}$ & $\begin{array}{l}\text { - Perbaikan Dekorasi, } \\
\text { penambahan wifi dan } \\
\text { asesoris } \\
\text { - Perluasan tempat usaha } \\
\text { melalui pameran }\end{array}$ & $\begin{array}{l}\text { - Terdapatnya wifi yang } \\
\text { membuat nyaman } \\
\text { pelanggan yang } \\
\text { menunggu } \\
\text { pemesanan. } \\
\text { - Ikut dalam even } \\
\text { kegiatan di Kota Kediri }\end{array}$ \\
\hline
\end{tabular}

\section{Kebijakan Promosi}

Dalam kegiatan promosi yang merupakan kegiatan penting dalam sebuah proses pemasaran, usaha ayam geprek Mbok Moro melakukan kegiatan promosi baik secara langsung ataupun melalui sosial media, kegiatan itu antara lain :

a. Kegiatan promosi secara langsung dari mouth to mouth, promosi dari mulut ke mulut dimana promosi usaha ini dikarenakan produk maupun pelayanan yang bagus juga kecepatan dalam penyajian.

b. Kegiatan promosi dengan mengikuti kegiatan kegiatan UMKM seperti car free day maupun apabila ada event pameran yang diselenggarakan baik oleh perguruan tinggi, sekolah maupun pemerintahan.

c. Kegiatan promosi juga melalui jejaring sosial dari facebook, instagarm maupun whatsapp.

Dari hasil wawancara dan observasi dapat dianalisis sebagai berikut :

Tabel 5. Standart Indikator Promosi Usaha Ayam Geprek Mbok Moro Kota Kediri

\begin{tabular}{|c|c|c|c|}
\hline Uraian & Standar indikator & Kondisi Saat ini & $\begin{array}{l}\text { Pengembangan usaha untuk } \\
\text { meningkatkan jumlah pembeli }\end{array}$ \\
\hline \multirow[t]{2}{*}{$\begin{array}{l}\text { Promotion / Promosi } \\
\text { Pengenalan produk, } \\
\text { branding merek, } \\
\text { program diskon, dll. }\end{array}$} & Pencanaan usaha & $\begin{array}{l}\text { Terdapat } \\
\text { perencanaan usaha } \\
\text { untuk memperluas } \\
\text { usaha, akan tetapi } \\
\text { belum maksimal }\end{array}$ & $\begin{array}{l}\text { Permasalahan: } \\
\text { Belum maksimalnya kemampuan } \\
\text { manajemen dalam perencanaan usaha } \\
\text { yang memadai }\end{array}$ \\
\hline & $\begin{array}{l}\text { Jejaring kemitraan dan } \\
\text { jejaring sosial }\end{array}$ & $\begin{array}{l}\text { Menggunakan jejaring } \\
\text { kemitraan dengan go } \\
\text { food dalam } \\
\text { memperlancar usaha } \\
\text { penjualan usaha } \\
\text { ayam geprek Mbok } \\
\text { Moro. }\end{array}$ & $\begin{array}{l}\text { Kebutuhan : } \\
\text { Perlu adanya peningkatan kemampuan } \\
\text { manajemen dalam merencanakan usaha. } \\
\text { Penggembangan Usaha } \\
\text { - Mengikuti pelatihan pelatihan yang } \\
\quad \text { diselenggarakan oleh pemerintah } \\
\text { maupun paguyupan UMKM }\end{array}$ \\
\hline
\end{tabular}


Efektor, Vol. 7. No.1 Tahun 2020, Pages 49-58

Forijati, Ridwan

\begin{tabular}{llll}
\hline Uraian & Standar indikator & Kondisi Saat ini & \multicolumn{1}{c}{$\begin{array}{c}\text { Pengembangan usaha untuk } \\
\text { meningkatkan jumlah pembeli }\end{array}$} \\
\hline & $\begin{array}{l}\text { Kemitraan juga } \\
\text { dengan pemasok } \\
\text { ayam dan pemasok } \\
\text { sayuran }\end{array}$ & - Meningkatkan brand \\
& & \\
\hline
\end{tabular}

SIMPULAN

Dari hasil analisis data dan pembahasan dapat disimpulkan sebagai berikut :

Pengembangan usaha ayam geprek Mbok Moro dengan analisis markekting mix adalah sebagai berikut : 1) dari segi produk, usaha ini membutuhkan manajemen kualitas mutu sehingga produknya dapat bersaing dengan usaha yang serupa salah satunya dengan variasi menu dan penggunaan teknologi dalam pengembangan usaha sehingga akan meningkatkan jumlah pembeli 2) dari segi harga, dengan mempertimbangkan berbagai faktor antara lain iklim usaha, pesaing dan bagaimana mengelola biaya sehingga dari segi harga, usaha ini akan bisa tetap bertahan dan diterima oleh pembeli 3) dari segi tempat (place), usaha ini memperoleh banyak pembeli dikarenakan tempat yang strategis, akan tetapi penataan interior/desain dari tempat usaha juga akan dapat menarik minat pembeli. 4) dari segi promosi, usaha ini menggunakan berbagai macam promosi antara lain promosi langsung, promosi dengan banner maupun melalui mediasosial. Dari hasil penelitian direkomendasikan untuk pengembangan usaha guna meningkatkan pembeli pada usaha ayam geprek Mbok Moro, adalah dengan memperkuat brand dan juga kompilasi antara produk, harga, tempat dan promosi, sehingga usaha ini dapat dipetakan dan dapat dikembangkan secara optimal.

\section{DAFTAR RUJUKAN}

Ali, Syed Ehtesham. 2008. Marketing Mix and The Reputation Of Nokia. Market Forces, 4: pp: 15-29.

Bennet, R.,Anthony. 1997. The Five Vs - a buyer's Perspective of The MarketingMix. Marketing Intelligence \& Planning, 15(3): pp: 151-156.

Buchari, Alma. 2004. Manajemen Pemasaran dan Pemasaran Jasa. Bandung: Alfabeta.

Cannon, Perreault, McCarthy, 2008, Pemasaran Dasar Pendekatan Manajerial Global, Buku 2 Edisi 16, Salemba Empat, Jakarta.

Creswell, J.W. 2013. Research Design: Pendekatan Kualitatif, Kuantitatif dan Mixed. Terjemahan Fawaid, A. Yogyakarta: Pustaka Pelajar.

Daryanto, L. H., dan Hasiholan, L. B. The Influence Of Marketing Mix On The Decision To Purchase Martabak "Setiabudi"Pak Man Semarang. Journal of Management, Vol. 5, No. 5, 2019.

Forijati, 2019, Strategi Pengembangan Usaha Dengan Model Bisnis Kanvas Pada Usaha Ayam Geprek Mbok Moro Kota Kediri, Proceeding Senmea, http://ojs.senmea.fe.unpkediri.ac.id/index.php/senmea/article/view/55.

Engel, J; Blackwell, R. 2004. Consumer Behavior. Dryden Press Chicago Andi, Yogyakarta.

Eriyanto. 2011. Analisis Isi: Pengantar Metodologi untuk Penelitian IImu Komunikasi dan IImu-ilmu Sosial Lainnya. Jakarta: Kencana.

Kotler, Philip, 2002, Manajemen Pemasaran, Edisi milinium, Jilid 2,Jakarta: PT Pren Hallindo.

Kotler, Philip dan Keller, Kevin Lane, 2008, Manajemen Pemasaran, Erlangga, Indonesia.

Lye, Ashley., Shao, Wei., Thiele,Sharyn Rundle. 2004. Decision waves: consumerdecisions in today's complexworld. European Journal of Marketing, 39(1/2): pp: 216-230. 


\section{Efektor, Vol. 7. No.1 Tahun 2020, Pages 49-58}

Forijati, Ridwan

Moleong, Lexy J. 2012. Metode Penelitian Kualitatif. Edisi Revisi. Bandung: Remaja Rosdakarya.

Oetama, Seanawati. 2011. Analisis Pengaruh Bauran Pemasaran Terhadap Keputusan Konsumen Dalam Pembelian Motor Honda di Sampit. Jurnal IImu Sosial, 3(1): h:40-53.

Rigopoulou, Irini, D., Chaniotakis, Ioannis, E., Lymperopoulos, Constantine., Siomkos, George I. 2008. After-Sales Service Quality As An Antecedent of Customer Satisfaction. Managing Service Quality, 18 (5): pp: 512527.

Selang, C. A. Bauran pemasaran (marketing mix) pengaruhnya terhadap loyalitas konsumen pada fresh mart Bahu Mall Manado. Jurnal EMBA:Jurnal Riset Ekonomi, Manajemen, Bisnis dan AkuntansiVol. 1, No. 3, 2013.

Sugiyono. 2014. Metode Penelitian Pendidikan Pendekatan Kuantitatif, Kualitatif dan R\&D. Bandung: Alfabeta.

Swastha, Basu, 2001, Manajemen PemasaranModern, Yogjakarta: Liberty,

Tjiptono Fandy. 1997. Strategi Pemasaran.Yogyakarta: Andi.

,2000, Strategi Pemasaran. Yogyakarta: Andi. 